\title{
UV/PAR radiation and DOM properties in surface coastal waters of the Canadian shelf of the Beaufort Sea during summer 2009
}

\author{
J. Para ${ }^{1}$, B. Charrière ${ }^{1}$, A. Matsuoka ${ }^{2,3}$, W. L. Miller ${ }^{4}$, J. F. Rontani ${ }^{1}$, and R. Sempéré ${ }^{1}$ \\ ${ }^{1}$ Aix-Marseille Université, Mediterranean Institute of Oceanography (MIO), 13288, Marseille, Cedex 9, France; \\ Université du Sud Toulon-Var, MIO, 83957, La Garde cedex, CNRS/INSU, MIO UMR7294, France \\ ${ }^{2}$ Laboratoire d'Océanographie de Villefranche, Université Pierre et Marie Curie (Paris 6)/ CNRS/INSU, B.P. 08, \\ Port de la Darse, Villefranche-sur-Mer Cedex, 06230, France \\ ${ }^{3}$ Takuvik Joint International Laboratory, Université Laval (Canada) - CNRS (France), Département de Biologie \\ and Québec-Océan, Université Laval, Pavillon Alexandre-Vachon 1045, Avenue de la Médecine, Local 2078, \\ G1V 0A6, Canada \\ ${ }^{4}$ UGAMI/UGA Marine Science, Athens, GA 30602, USA
}

Correspondence to: R. Sempéré (richard.sempere@univ-amu.fr)

Received: 2 October 2012 - Published in Biogeosciences Discuss.: 5 November 2012

Revised: 3 April 2013 - Accepted: 4 April 2013 - Published: 26 April 2013

\begin{abstract}
Surface waters from the Beaufort Sea in the Arctic Ocean were evaluated for dissolved organic carbon (DOC), and optical characteristics including UV (ultraviolet) radiation and PAR (photosynthetically active radiation) diffuse attenuation $\left(K_{\mathrm{d}}\right)$, and chromophoric and fluorescent dissolved organic matter (CDOM and FDOM) as part of the MALINA field campaign (30 July to 27 August). Spectral absorption coefficients $\left(a_{\mathrm{CDOM}}(350 \mathrm{~nm})\left(\mathrm{m}^{-1}\right)\right)$ were significantly correlated to both diffuse attenuation coefficients $\left(K_{\mathrm{d}}\right)$ in the UV-A and UV-B and to DOC concentrations. This indicates CDOM as the dominant attenuator of both UV and PAR solar radiation and suggests its use as an optical proxy for DOC concentrations in this region. While the Mackenzie input is the main driver of CDOM dynamics in low salinity waters, locally, primary production can create significant increases in CDOM. Extrapolating CDOM to DOC relationships, we estimate that $\sim 16 \%$ of the DOC in the Mackenzie River does not absorb radiation at $350 \mathrm{~nm}$. The discharges of DOC and its chromophoric subset (CDOM) by the Mackenzie River during the MALINA cruise are estimated as $\sim 0.22 \mathrm{TgC}$ and $0.18 \mathrm{TgC}$, respectively. Three dissolved fluorescent components $(\mathrm{C} 1-\mathrm{C} 3)$ were identified by fluorescence excitation/emission matrix spectroscopy (EEMS) and parallel factor (PARAFAC) analysis. Our results showed an aquatic dissolved organic matter (DOM) component (C1), probably produced in the numerous lakes of the watershed,
\end{abstract}

that co-dominated with a terrestrial humic-like component (C2) in the Mackenzie Delta Sector. This aquatic DOM could partially explain the high CDOM spectral slopes observed in the Beaufort Sea.

\section{Introduction}

Even though the Arctic Ocean comprises only $\sim 1 \%$ of the earth's total ocean volume and $\sim 3 \%$ of its surface area, it currently receives $\sim 11 \%$ of the global river runoff (Opsahl et al., 1999). Moreover, the effects of climate change are more pronounced toward the earth's poles. Increasing air temperatures $\left(+3\right.$ to $4{ }^{\circ} \mathrm{C}$; IPCC, 2007) enhance numerous biogeochemical changes, particularly by affecting the integrity of the permafrost (Guo et al., 2007; Walvoord and Striegl, 2007). Approximately $50 \%$ of the global terrestrial organic carbon pool is trapped in Arctic and sub-Arctic permafrost regions (Tarnocai et al., 2009) that are now warming (Foley, 2005). Therefore, increases in freshwater discharge coupled with changes in the mobility of terrestrial dissolved organic matter (DOM) are expected to increase DOM flux at high latitudes (Lawrence and Slater, 2005). This could lead to increased delivery of terrestrial DOM to the Arctic Ocean, as well as modified water circulation and sea ice coverage (Barber and Hanesiak, 2004). 
Arctic rivers usually exhibit high organic matter content and low nutrient concentrations, especially for nitrogen and phosphorus (Dittmar and Kattner, 2003). The DOM content in the Western Arctic region of the Beaufort Sea is strongly impacted by freshwater inputs from the Mackenzie River, which currently contributes the fourth-largest freshwater discharge to the Arctic (Gordeev, 2006) and is the dominant source of terrestrial DOM to this region. River discharge, approximately $330 \mathrm{~km}^{3} \mathrm{yr}^{-1}$ varies from $4000 \mathrm{~m}^{3} \mathrm{~s}^{-1}$ during winter (from December to May) to about $25000 \mathrm{~m}^{3} \mathrm{~s}^{-1}$ during summer (from June to August) (e.g. O'Brien et al., 2006). The Mackenzie's flux of dissolved organic carbon (DOC) to the coastal Beaufort Sea is estimated to be $\sim 1.04-1.76 \mathrm{TgC}$ per year (Raymond et al., 2007).

The chromophoric fraction of DOM (CDOM) that absorbs solar irradiation over a broad range of ultraviolet (UV) and visible wavelengths is also delivered by the Mackenzie River. During the spring freshet and ice break-up, this increased amount of terrestrial CDOM in coastal areas can have numerous biological, chemical and physical effects. The presence of terrestrial CDOM decreases the euphotic depth for primary production, increases photo-oxidation (i.e. $\mathrm{CO}$ and $\mathrm{CO}_{2}$ production) and increases mineralization of terrestrial DOC by stimulation of heterotrophic bacteria through the photo-production of labile organic substrates (Osburn et al., 2009). The combination of low sunlight intensity due to high solar zenith angles, large variations in seasonal day length, the influence of sea ice cover on sunlight penetration in surface waters, plume dynamics of the Mackenzie, and the changing DOM photochemical and biological reactivity in relation to season (Emmerton et al., 2008) all create a complex and highly variable photochemical environment over the Canadian shelf (Johannessen and Miller, 2001; Osburn et al., 2009). Consequently, in this Arctic environment that is so susceptible to the forcings of future climate change, better knowledge of the source, composition and surface distribution of CDOM, along with its effects on in situ optical characteristics, is crucial to better quantify the processes involved in the organic carbon cycle in surface waters and at the land/sea interface.

Here, we report the spatial distribution of CDOM optical properties, in-air and in-water sunlight optical characteristics, and their evolving patterns in surface coastal waters of the Canadian shelf of the Beaufort Sea during the summer of 2009. CDOM optical properties in sampled water, in combination with three-dimensional excitation/emission matrix spectroscopy (EEMS) and parallel factor (PARAFAC) analysis, were also examined to (i) define CDOM spectral absorbance features, (ii) identify and characterize the primary DOM fluorescent components and (iii) trace the corresponding spatial distributions of these signals in surface waters of the Canadian Arctic shelf.

\section{Materials and methods}

\subsection{Study site and sample collection}

Hydrological samples were collected from surface waters at 27 stations over the Canadian shelf of the Beaufort Sea onboard the research ice-breaker CCGS Amundsen during the Mackenzie Light and Carbon (MALINA) cruise held from 30 July to 27 August 2009 (Fig. 1 and 2). During this open water study period, the Mackenzie discharge was approximately $12000 \mathrm{~m}^{3} \mathrm{~s}^{-1}$ (http://www.ec.gc.ca/rhc-wsc/) and the area investigated was characterized by an unusual ice cover extent and predominately overcast weather. According to the freshwater influence of the Mackenzie River estimated from the salinity $(S)$, three different sectors were defined including Mackenzie Delta sector $(S<15)$, North West sector $(S<23)$ and North East sector $(S>23)$. Samples were collected using Niskin bottles equipped with Teflon O-rings and silicon tubes to avoid chemical contamination. For fluorescence determination, samples were directly transferred from the Niskin bottle through a Polycap AS 75 (Whatman ${ }^{\circledR}$ ) $0.2 \mu \mathrm{m}$ nylon filter membrane cartridge into precombusted $\left(6 \mathrm{~h}\right.$ at $\left.450^{\circ} \mathrm{C}\right)$ glass ampoules and stored at $-20^{\circ} \mathrm{C}$ in the dark until analyses. Polycap AS 75 were washed with HCL $5 \%$, then with $5 \mathrm{~L}$ of Milli-Q (Millipore ${ }^{\circledR}$ ) water and finally rinsed with $4-5 \mathrm{~L}$ of sea water before sampling. A new Polycap AS 75 filter was used for each sample. The $0.2 \mu \mathrm{m}$ filtration avoids rupture of microbial cells during the freeze-thaw cycle and thus minimized changes in fluorescence properties due to storage (Yamashita et al., 2010). However, labile protein-like materials could be degraded during storage, thus protein-like $\mathrm{C} 3$ fluorophore will not be discussed in this article. For CDOM, samples were transferred from Niskin bottles into $10 \% \mathrm{HCl}$-washed and precombusted $(6 \mathrm{~h}$ at $450^{\circ} \mathrm{C}$ ) glass bottles covered with aluminium foil and directly filtered in dim light using $0.2 \mu \mathrm{m}$ GHP filters (Acrodisc Inc.) pre-rinsed with $200 \mathrm{~mL}$ of Milli-Q water. DOC samples were sampled online with the Niskin bottle using a Millipore Swinnex-47 cartridge holder equipped with a precombusted $\left(6 \mathrm{~h}\right.$ at $\left.450^{\circ} \mathrm{C}\right) 0.7 \mu \mathrm{m} \mathrm{GF} / \mathrm{F}$ filters, which had been pre-rinsed with Milli-Q water and with samples. Ampoules were immediately acidified with $85 \% \mathrm{H}_{3} \mathrm{PO}_{4}$ (final $\mathrm{pH} 2$ ) and flame sealed. During sampling, in situ hydrological context (temperature and salinity vs. depth) was determined with a SeaBird Electronics 911 CTD profiler (Table 1).

\subsection{Radiometric measurements}

Duplicate in situ profiles of downward irradiance $\left(E_{\mathrm{d}}(\mathrm{z}, \lambda)\right.$; $\mu \mathrm{W} \mathrm{cm} \mathrm{cm}^{-2} \mathrm{~nm}^{-1}$ ) were performed, under mainly overcast skies, at 16 sampling stations (Fig. 1) using a Satlantic MicroPro ${ }^{\circledR}$ free-fall profiler equipped with OCR-504 irradiance sensors that measure the UV-B (305 nm), UV-A ( 325 , 340 and $380 \mathrm{~nm}$ ) and PAR (photosynthetically active radiation; 412, 443, 490 and $565 \mathrm{~nm}$ ) spectral domains (Tedetti 


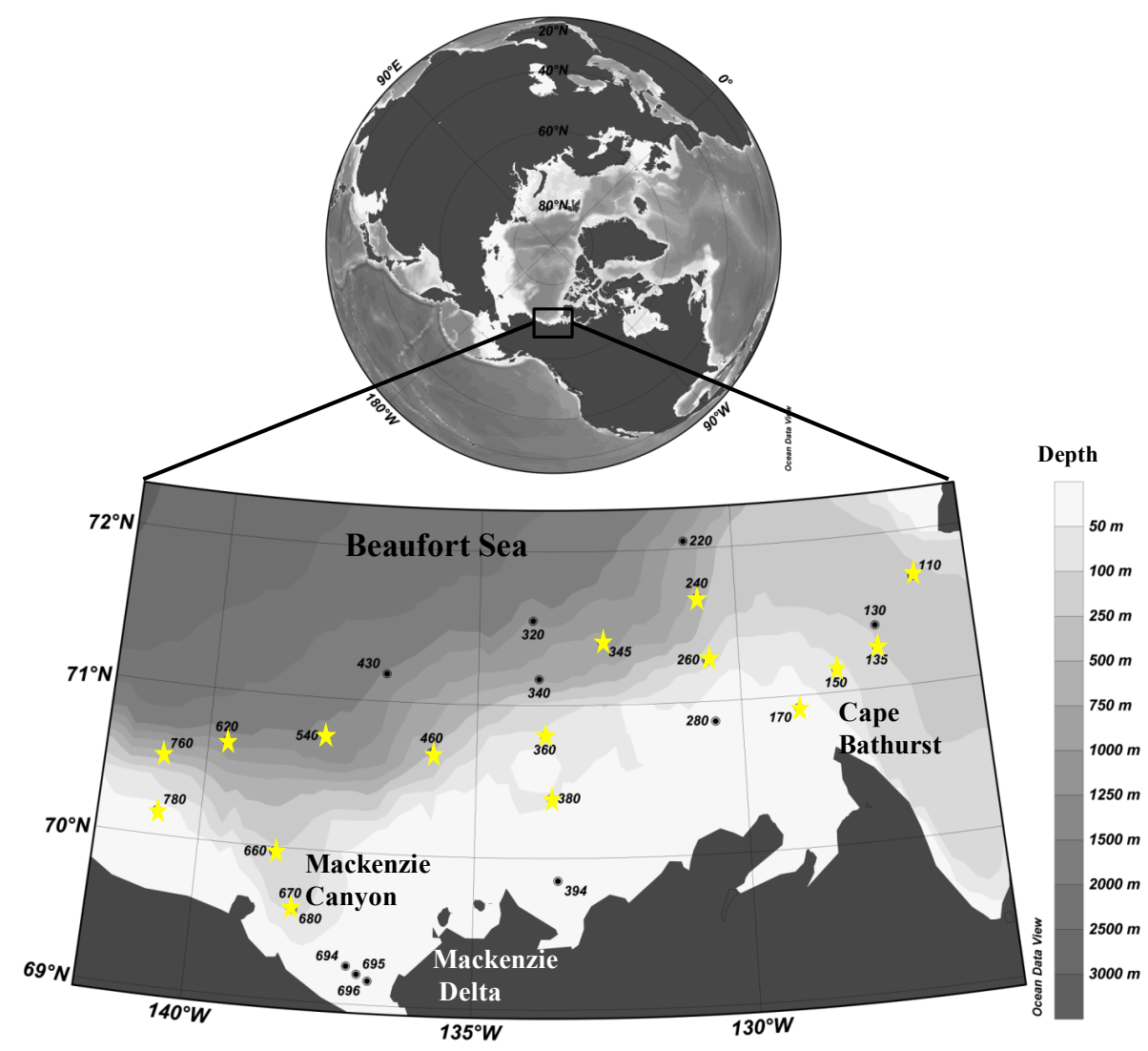

Fig. 1. Locations and station numbers investigated during the MALINA cruise over the Canadian shelf of the Beaufort Sea. Yellow stars represent the stations where profiles of downward irradiance were performed.

et al., 2007). Surface irradiance $\left(E_{\mathrm{s}}(\lambda)\right.$ in $\left.\mu \mathrm{W} \mathrm{cm} \mathrm{cm}^{-2} \mathrm{~nm}^{-1}\right)$ was simultaneously measured at the same wavebands on the ship's roof with matching OCR-504 sensors to account for variations in the sky conditions during the cast as well as to monitor UV and PAR solar irradiance during the day. For both the in-water and in-air OCR-504 sensors, the full width at half maximum (FWHM) was $2 \mathrm{~nm}$ for the 305, 325 and $340 \mathrm{~nm}$ channels and $10 \mathrm{~nm}$ for the PAR channels. The MicroPro ${ }^{\circledR}$ free-fall profiler, equipped with pressure, temperature and tilt sensors, was deployed from the front of the ship and profiled $\sim 50 \mathrm{~m}$ away to minimize shadowing effects and disturbances.

Each cast was accompanied by a measurement of the dark current (instrument on deck) and a pressure tare (instrument at sea surface). To obtain as many valid measurements as possible (i.e. tilt $<5^{\circ}$ ), the profiler was nose ballasted to provide a descent rate of $\sim 70 \mathrm{~cm} \mathrm{~s}^{-1}$ at a sampling rate of $7 \mathrm{~Hz}$ (i.e. sampling resolution of $10 \mathrm{~cm}$ ). Measurements were logged using Satlantic's Satview ${ }^{\circledR} 2.6$ software. This allowed for initial data processing, such as channel integration for PAR calculations, radiometric calibration, dark correction, pressure tare application and the removal of data with tilt $>5^{\circ}$. Satview ${ }^{\circledR}$, s data interpolation option was not used, choosing rather to work with the raw radiometric data for $K_{\mathrm{d}}$ calculations. Profiles of downwelling irradiance in the total PAR range were calculated by Prosoft Satlantic software from the four PAR channels.

The diffuse attenuation coefficients for downwelling UV radiation and PAR irradiances $\left(K_{\mathrm{d}}(\lambda) \mathrm{m}^{-1}\right)$ were calculated, assuming a homogeneous surface mixed layer, as the slope of the best-fit linear regression for the log-transformed downwelling irradiance data vs. depth relationship defined by the following equation:

$E_{\mathrm{d}}(z, \lambda)=E_{\mathrm{d}}\left(0^{-}, \lambda\right) \exp ^{\left(-K_{\mathrm{d}}(\lambda)^{z}\right)}$.

$E_{\mathrm{d}}\left(0^{-}, \lambda\right)$, the downwelling irradiance just beneath the sea surface, was computed from above-water deck irradiance measurements, $E_{\mathrm{d}}\left(0^{+}, \lambda\right)$, using the theoretical relationship defined by Smith and Baker (1984):

$\operatorname{Ed}\left(0^{-}, \lambda\right)=\operatorname{Ed}\left(0^{+}, \lambda\right) /(1+\alpha)$,

where $\alpha$ is is the Fresnel reflection albedo for irradiance from sun and sky determined using a "look-up table" (Jin et al., 2004; http://snowdog.larc.nasa.gov/jin/getocnlut.html) based on the validated Coupled Ocean-Atmosphere Radiative Transfer (COART) model. Because attenuation in natural waters is known to decrease with increasing wavelength 
Table 1. Bottom depth, temperature, salinity, DOC and absorbance properties, including CDOM absorption coefficient, specific absorption coefficient at $350 \mathrm{~nm}\left(a_{\mathrm{CDOM}} *(350)\right)$ and the spectral slope determined in surface waters of each sampling station and among the different sectors investigated (i.e. North East, North West and Mackenzie Delta sectors) observed.

\begin{tabular}{|c|c|c|c|c|c|c|c|}
\hline Station & $\begin{array}{r}\text { Bottom } \\
\text { depth }(m)\end{array}$ & $\begin{array}{r}\text { Temperature } \\
\left({ }^{\circ} \mathrm{C}\right)\end{array}$ & Salinity & $\begin{array}{l}\text { DOC } \\
(\mu \mathrm{M})\end{array}$ & $\begin{array}{r}a_{\mathrm{CDOM}}(350) \\
\left(\mathrm{m}^{-1}\right)\end{array}$ & 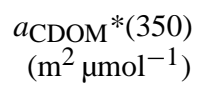 & $\begin{array}{l}S_{\mathrm{CDOM}} \\
\left(\mathrm{nm}^{-1}\right)\end{array}$ \\
\hline \multicolumn{8}{|c|}{ North East Sector } \\
\hline 150 & 65 & 3.55 & 29.41 & 84 & 0.29 & 3.51 & 0.020 \\
\hline 170 & 37 & 3.19 & 29.37 & 115 & 0.56 & 4.89 & 0.018 \\
\hline 260 & 59 & 4.61 & 29.26 & 80 & 0.19 & 2.32 & 0.019 \\
\hline 110 & 407 & 4.36 & 28.93 & 75 & 0.14 & 1.89 & 0.019 \\
\hline 240 & 475 & 3.23 & 28.90 & 62 & & & \\
\hline 130 & 310 & 4.63 & 28.22 & 68 & 0.17 & 2.53 & 0.019 \\
\hline 135 & 227 & 2.24 & 28.05 & 67 & 0.15 & 2.19 & 0.020 \\
\hline 380 & 62 & 4.41 & 27.67 & 74 & 0.21 & 2.88 & 0.019 \\
\hline 280 & 41 & 4.71 & 27.63 & 89 & 0.38 & 4.21 & 0.019 \\
\hline 223 & 940 & -0.07 & 27.54 & 66 & 0.15 & 2.31 & 0.019 \\
\hline 345 & 586 & 1.96 & 27.49 & 62 & 0.12 & 1.95 & 0.020 \\
\hline 340 & 559 & 0.13 & 26.87 & 61 & 0.13 & 2.09 & 0.020 \\
\hline 320 & 1134 & -0.78 & 26.52 & 58 & 0.13 & 2.28 & 0.019 \\
\hline 360 & 76 & -0.17 & 26.47 & 62 & 0.12 & 2.01 & 0.021 \\
\hline 540 & 1511 & -0.41 & 25.73 & 61 & 0.16 & 2.60 & 0.023 \\
\hline 430 & 1282 & -0.78 & 25.96 & 59. & 0.14 & 2.37 & 0.022 \\
\hline 460 & 357 & -0.09 & 24.78 & 58 & 0.19 & 3.26 & 0.021 \\
\hline Mean & 478 & 2.04 & 27.58 & 71 & 0.20 & 2.71 & 0.020 \\
\hline SD & 471 & 2.18 & 1.38 & 15 & 0.12 & 0.86 & 0.001 \\
\hline \multicolumn{8}{|c|}{ North West Sector } \\
\hline 760 & 543 & 0.54 & 22.52 & 73 & 0.43 & 5.80 & 0.019 \\
\hline 620 & 1541 & 2.07 & 22.06 & 94 & 0.77 & 8.20 & 0.019 \\
\hline 660 & 259 & 4.25 & 21.90 & 104 & 0.77 & 7.38 & 0.019 \\
\hline 670 & 124 & 5.39 & 21.86 & 105 & & & \\
\hline 394 & 11 & 8.81 & 21.45 & 200 & 2.28 & 11.42 & 0.017 \\
\hline 780 & 49 & 4.10 & 21.08 & 110 & 0.77 & 6.97 & 0.019 \\
\hline Mean & 421 & 4.19 & 21.81 & 114 & 1.00 & 7.95 & 0.019 \\
\hline SD & 581 & 2.85 & 0.50 & 44 & 0.73 & 2.12 & 0.001 \\
\hline \multicolumn{8}{|c|}{ Mackenzie Delta Sector } \\
\hline 680 & 121 & 8.05 & 14.76 & 188. & 2.35 & 12.49 & 0.018 \\
\hline 694 & 11 & 9.28 & 9.43 & 316. & 5.05 & 15.96 & 0.019 \\
\hline 695 & 4 & 9.56 & 7.56 & 342 & 5.60 & 16.39 & 0.019 \\
\hline 696 & 3 & 10.08 & 0.23 & 394 & 6.36 & 16.13 & 0.020 \\
\hline Mean & 35 & 9.24 & 8.00 & 293 & 4.84 & 15.24 & 0.019 \\
\hline SD & 58 & 0.86 & 6.01 & 120 & 1.74 & 1.84 & 0.001 \\
\hline
\end{tabular}

in the UV range, any $K_{\mathrm{d}}(\lambda)$ value that was lower than those at longer wavelengths was deleted. Values of $K_{\mathrm{d}}(\lambda)$ at $305 \mathrm{~nm}$ were particularly prone to error. The mean variability (CV \%) of $K_{\mathrm{d}}(\mathrm{UV})$ and $K_{\mathrm{d}}(\mathrm{PAR})$ determined between duplicate profiles was within $3 \%$.

\subsection{DOC analysis}

The Shimadzu instrument used in this study is the commercially available model TOC-5000 Total Organic Carbon Analyzer with a quartz combustion column filled with $1.2 \% \mathrm{Pt}$ on silica pillows with modifications previously described in Sohrin and Sempéré (2005).

Calibration of the instrument was performed daily using Milli-Q acidified with $\mathrm{H}_{3} \mathrm{PO}_{4}$ water as blank and potassium 


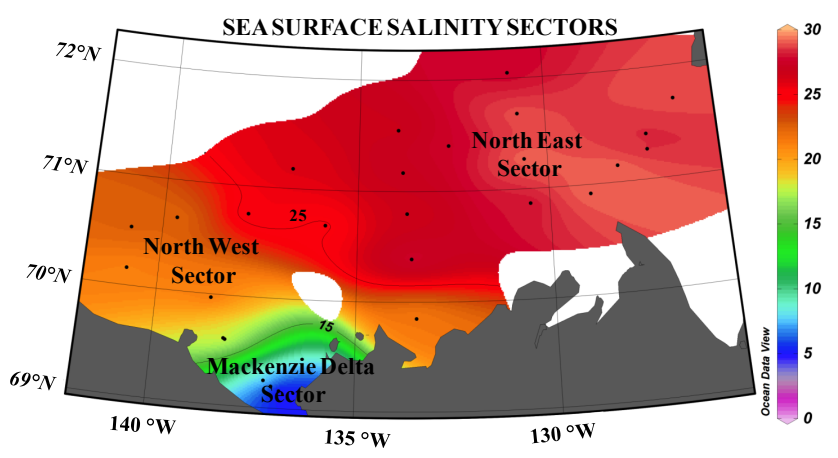

Fig. 2. Map of the sea surface salinity illustrating the different surface salinity sectors observed during the study: Mackenzie Delta Sector (salinity $<15)$, North West Sector $(15<$ salinity $<25)$ and North East Sector (salinity $>25$ ). Isohalines 15 and 25 mark the boundaries of these sectors.

hydrogen phthalate diluted in Milli-Q water and acidified with $\mathrm{H}_{3} \mathrm{PO}_{4}$ (range $0-400 \mu \mathrm{MC}$, five points) prepared just before sample analysis as a standard. The running blank was determined as the average of the peak area of the Milli-Q water acidified with $\mathrm{H}_{3} \mathrm{PO}_{4}$. The DOC concentrations were determined by subtracting the running blank from the average peak area of the samples ( $n=4$ or 5$)$ and dividing the result by the slope of the calibration curve. The acidified Milli-Q water was injected in triplicate after every 4 samples. The measurement accuracy and the system blank of our instrument were determined by the analysis of seawater reference material (D. Hansell, Rosenstiel School of Marine and Atmospheric Science, Miami, USA), including Deep Atlantic Water (DAW) and Low Carbon Water (LCW) reference standards. The average DOC concentrations in the DAW and in the LCW reference standards were $45 \pm 2 \mu \mathrm{M} \mathrm{C}(\mathrm{n}=24)$ and $1 \pm 0.3 \mu \mathrm{M} \mathrm{C}(n=24)$, respectively. Carbon levels in the LCW ampoules were similar to and often higher than the Milli-Q water produced in our laboratory. The nominal analytical precision for the procedure was $2 \%$ or less.

\subsection{CDOM optical properties}

\subsubsection{Absorbance measurements}

After collection and filtration of the samples, CDOM absorbance (280-700 nm) was measured onboard (within 24 h) using a multiple pathlength, liquid core UltraPath waveguide system (MPLCW; WPI Inc.). The detailed methodology for determining light absorbance of CDOM (280-735 nm) using this system is documented in Matsuoka et al. (2012) (this issue). Spectral absorption coefficients, $a_{\mathrm{CDOM}}(\lambda)\left(\mathrm{m}^{-1}\right)$ were obtained using the following relationship:

$a_{\mathrm{CDOM}}(\lambda)=2.303 \mathrm{~A}(\lambda) / L$,

where $\mathrm{A}(\lambda)$ (dimensionless) is the absorbance at wavelength $\lambda(\mathrm{nm})$ and $L$ is the pathlength in meters. The value of the spectral slope coefficient for the CDOM spectrum ( $\left.S_{\mathrm{CDOM}}\right)$ was determined by fitting a non-linear exponential regression to the original $a_{\mathrm{CDOM}}(\lambda)$ data over the $350-500 \mathrm{~nm}$ spectral range (Stedmon et al., 2000; Babin et al., 2003; Matsuoka et al., 2011, 2012). The $a_{\mathrm{CDOM}}(\lambda)$ at $350 \mathrm{~nm}\left(a_{\mathrm{CDOM}}(350)\right)$ was used as a proxy for the absorbent DOC. The specific absorption coefficient at $350 \mathrm{~nm}, a_{\mathrm{CDOM}} *(350)$, was calculated as $a_{\mathrm{CDOM}}(350) / \mathrm{DOC}\left(\mathrm{m}^{2} \mu \mathrm{MC}^{-1}\right)$ to estimate the efficiency with which DOC absorbs UV radiation and is used in this study to provide insight on the origin and types of CDOM in the Beaufort Sea.

\subsubsection{Fluorescence measurements}

For fluorescence measurements, samples were stored in the dark at $-20^{\circ} \mathrm{C}$, transported frozen to the MIO laboratory, and analyzed within 3 months of sampling. Thawed samples were transferred to a $1 \mathrm{~cm}$ pathlength far UV silica quartz cuvette (170-2600 nm; LEADER LAB), thermostated at $4{ }^{\circ} \mathrm{C}$ and analyzed with a Hitachi (Japan) Model F-7000 spectrofluorometer. Instrument settings, measurement protocol and spectral correction procedures are fully described in Tedetti et al. (2010) and Para et al. (2011). Briefly, the spectral correction for the instrumental response was conducted according to the procedure recommended by Hitachi (Hitachi F-7000 Instruction Manual). First, the excitation (Ex) instrumental response was obtained by using a rhodamine B standard and a single-side frosted red filter in the Ex scan mode. The emission (Em) calibration was performed with a diffuser in synchronous scan mode. The Ex and Em spectra obtained over the range $240-550 \mathrm{~nm}$ were applied internally as the instrument blank to correct subsequent spectra.

EEM spectra were generated using Ex wavelengths from 240 to $550 \mathrm{~nm}$ ( $5 \mathrm{~nm}$ intervals), Em wavelengths from 300 to $550 \mathrm{~nm}$ ( $2 \mathrm{~nm}$ intervals), a scan speed of $2400 \mathrm{~nm} \mathrm{~min}{ }^{-1}$ and $5 \mathrm{~nm}$ bandwidths (full width at half maximum; FWHM) for both Ex and Em. Milli-Q water was analyzed to normalize all fluorescence data (blanks, standards, samples) to be normalized to the intensity of the Raman scatter peak at Ex/Em: 275/303 nm (5 nm bandwidths) (Coble et al., 1993; Coble, 1996; Belzile et al., 2006). Solutions of quinine sulfate (Fluka) in $0.05 \mathrm{M} \mathrm{H}_{2} \mathrm{SO}_{4}(1-10 \mathrm{ppb})$ were also analyzed and fluorescent dissolved organic matter (FDOM) data were converted into quinine sulfate units (QSU) to further normalize fluorescence results and to allow comparison to previously published work.

The complex mixture of fluorophores that contribute to the total FDOM signal was then statistically decomposed into its primary components using the PARAFAC statistical tool based on an alternating least squares (ALS) algorithm (Stedmon et al., 2003). The analysis was carried out in MATLAB 7.1 with the DOMFluor toolbox (Stedmon and Bro, 2008), freely downloadable from the Chemometrics site at the University of Copenhagen (www.models.life.ku.dk). Implementation of the toolbox for our data set followed 


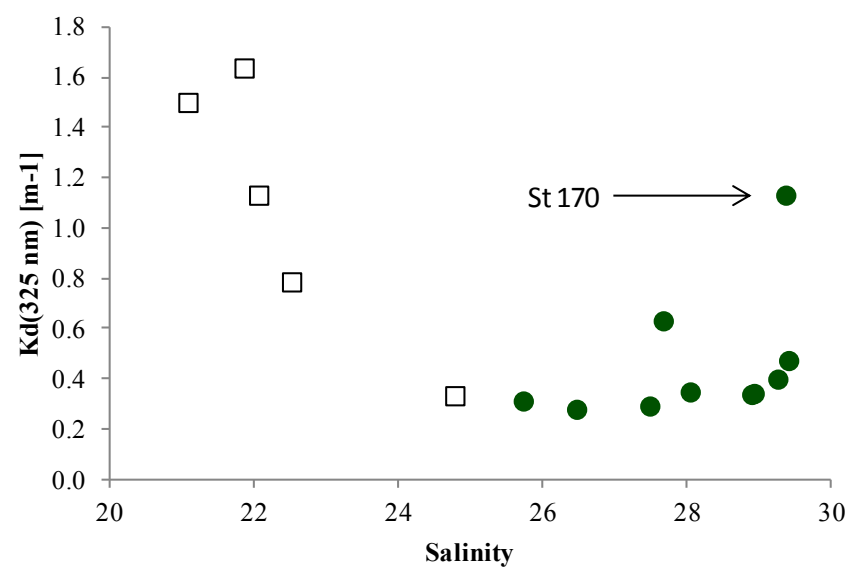

Fig. 3. Diffuse attenuation coefficient of light for $K_{\mathrm{d}}$ at $325 \mathrm{~nm}$ as a function of surface salinity in the North East (circles) and North West (squares) sectors. Station 170 was characterized by high DOC $(115 \mu \mathrm{M})$, chlorophyll $a\left(1.72 \mu \mathrm{g} \mathrm{L}^{-1}\right)$, primary productivity $\left(37.9 \mathrm{mgC} \mathrm{m}^{-3} \mathrm{~d}^{-1}\right)$ and $a_{\mathrm{CDOM}}(350)\left(0.56 \mathrm{~m}^{-1}\right)$ content. A similar pattern was observed for 340 and $380 \mathrm{~nm}$ wavelengths and for PAR spectral domain.

protocols presented in Stedmon and Bro (2008). A threecomponent PARAFAC model was validated using split-half analysis (Stedmon et al., 2003) and provided low residual values when compared to EEM spectra obtained from the original samples, thus confirming the model's ability to extract the majority of the samples' fluorescent features and appropriately characterize the surface FDOM composition for this area.

\section{Results and discussion}

\subsection{Surface irradiance at sea surface and diffuse attenuation coefficient of light in surface waters}

During the MALINA cruise, the mean daily doses $\left(\mathrm{kJ} \mathrm{m}^{-2}\right)$ of UV-B $(305 \mathrm{~nm})$, UV-A $(380 \mathrm{~nm})$ and PAR incident on the sea surface were $0.12 \pm 0.03,8.46 \pm 1.64$ and $18.09 \pm 4.20 \mathrm{~kJ} \mathrm{~m}^{-2}$, respectively. These mean daily doses were low and relatively constant throughout the study period due to the presence of persistent clouds that reduced the overall incident solar radiation and particularly the UV-B. Thus, photochemical processes were probably limited during the summer of 2009 in the Beaufort Sea. For comparison, such daily doses for UV-B (305 nm), UV-A (380) and PAR $(490 \mathrm{~nm})$ were 10-, 2- and 1.5-fold lower, respectively, than those received at the sea surface in the South Pacific gyre during (austral) summer cloudy days (Sempéré et al., 2008).

Because the overall surface irradiance Es(UV-B) was notably weak, the determination of $K_{\mathrm{d}}(\mathrm{UV}-\mathrm{B})$ for approximately $50 \%$ of the stations sampled was not possible, particularly for the "organic-rich stations" located mostly in the

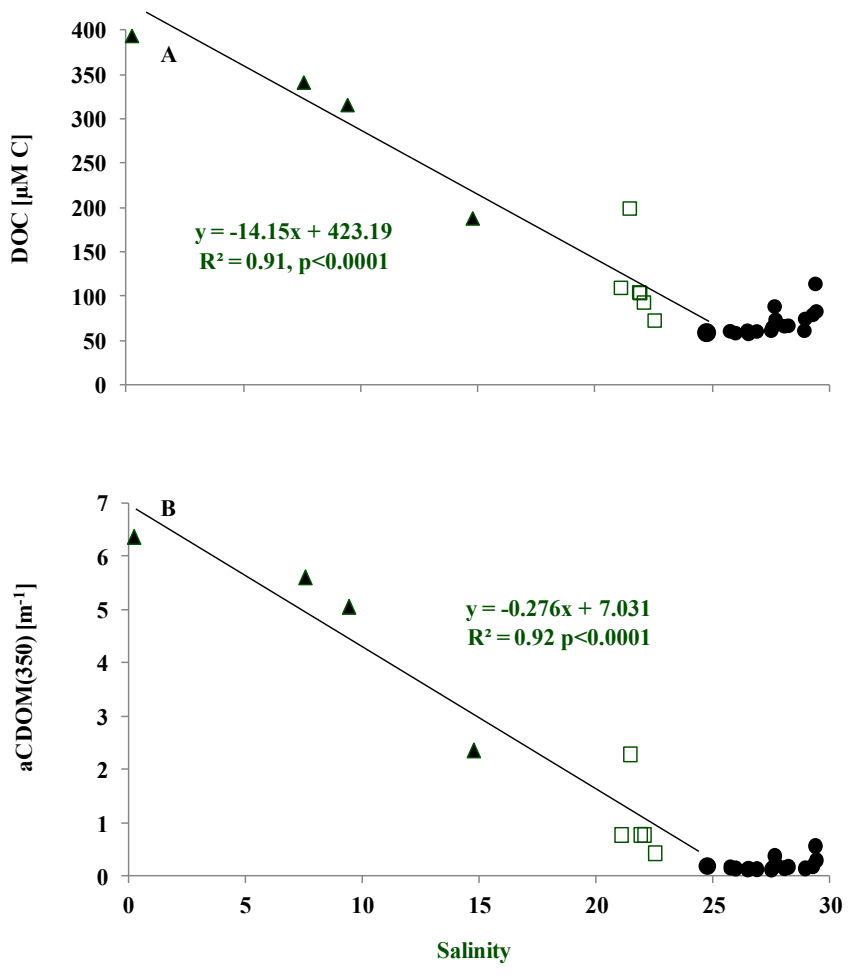

Fig. 4. Dissolved organic carbon (A) and spectral absorption coefficients $a_{\mathrm{CDOM}}(350)$ (B) as a function of surface salinity in the North East (circles), North West (squares) and Mackenzie Delta (triangles) sectors. Linear regressions are given for the North West and Mackenzie Delta sectors.

vicinity of the Mackenzie Delta (salinity $\leq 25$; Table 2). Consequently, $K_{\mathrm{d}}(305 \mathrm{~nm})$ is not discussed extensively in the following section. $K_{\mathrm{d}}(\lambda)$ values determined in both the UVA and PAR spectral domains showed strong variation among the 16 sampling stations monitored in the North West Sector. Both $K_{\mathrm{d}}(\mathrm{UV}-\mathrm{A})$ and $K_{\mathrm{d}}(\mathrm{PAR})$ increased with lower salinity, whereas values remained roughly constant or increased slightly for stations with salinity higher than 28 in the North East Sector (Fig. 3; Table 2). The downwelling attenuation of both UV-A and PAR in the North West Sector appeared to be mainly controlled and strongly impacted by CDOM carried by the Mackenzie River plume, while in the saltiest surface waters (North East Sector) other CDOM sources (primary production, CDOM production by bacterioplankton) appeared to have the ability to increase attenuation of both UV-A and PAR almost as strongly as the river plume. Note that the effect on light attenuation by the Mackenzie River discharge can be more important at other times of the year, since the discharge during the MALINA study period was relatively moderate $\left(12000 \mathrm{~m}^{3} \mathrm{~s}^{-1}\right)$. 


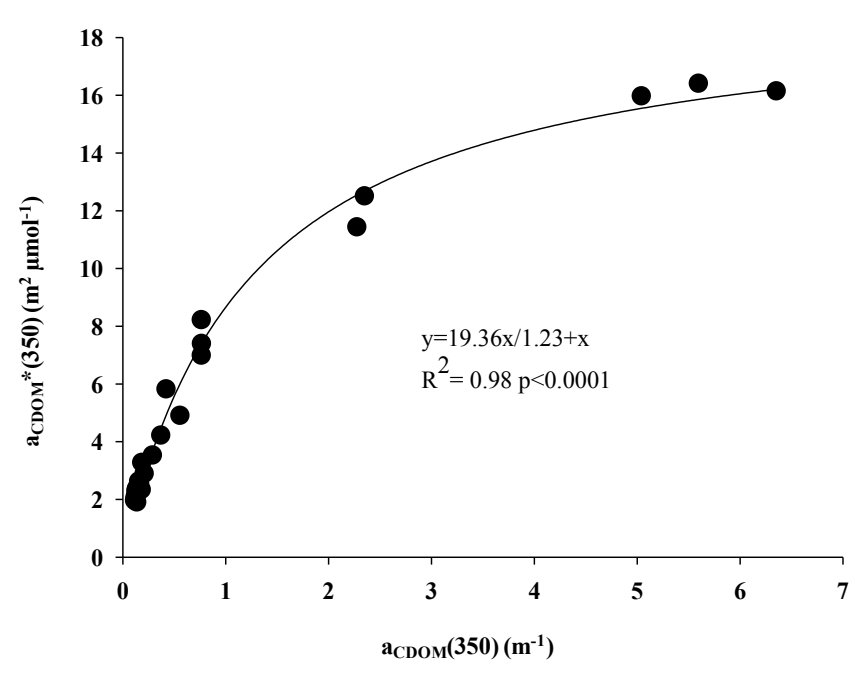

Fig. 5. Relationship between specific absorption coefficient at $350 \mathrm{~nm}\left(a_{\mathrm{CDOM}}{ }^{*}(350)\right)$ and $a_{\mathrm{CDOM}}(350)$ in the Mackenzie Delta and North West sectors.

\subsection{DOM characteristics}

\subsubsection{Dissolved organic carbon (DOC) and chromophoric DOM}

DOC concentration varied from 58 to $394 \mu \mathrm{M}$ in surface water of the Beaufort Sea during summer 2009 (Table 1), within the range reported by Emmerton et al. (2008). The minimum DOC value $(46 \mu \mathrm{M})$ was measured in the deep waters at station 620 (1750 $\mathrm{m}$ depth). This value can be considered as the deep refractory component of the DOC pool in this area. The DOC distribution among the three surface water salinity sectors observed for the Canadian shelf increased from $71 \pm 15 \mu \mathrm{M} \mathrm{C}$ in the North East Sector (salinity $\geq 25$ ) to $106 \pm 45$ and $310 \pm 87 \mu \mathrm{MC}$ in the North West $(15<$ salinity $<25$ ) and Mackenzie Delta (salinity $<15$ ) sectors, respectively (Table 1, Fig. 4). As shown by salinity distribution (Fig. 2), the western channel was more influenced by the river plume than the eastern channel. Relationships between DOC and salinity indicated a near-conservative behaviour when salinity was less than 25 .

Similar to the DOC distributions, $a_{\mathrm{CDOM}}(350)$ increased from $0.20 \pm 0.12$ in the North East Sector (salinity $\geq 25)$ to $1.00 \pm 0.73 \mathrm{~m}^{-1}$ in the North West Sector $(15<$ salinity $<25)$ and $4.84 \pm 1.74 \mathrm{~m}^{-1}$ in the Mackenzie Delta (salinity $<15$ ) Sector, being maximum near the river mouth (Table 1; Fig. 4). We found a negative correlation between $a_{\mathrm{CDOM}}(350)$ and salinity for $\mathrm{S}<25$ that indicates a near-conservative behaviour of CDOM in the river plume.

A similar pattern was observed for the specific absorption coefficient at $350 \mathrm{~nm}\left(a_{\mathrm{CDOM}} *(350)\right)$ with salinity, which is consistent with previous observations reported in the South Atlantic Bight and Mid-Atlantic Bight (Del Vecchio and Blough, 2004; Kowalczuk et al., 2009). Plotting

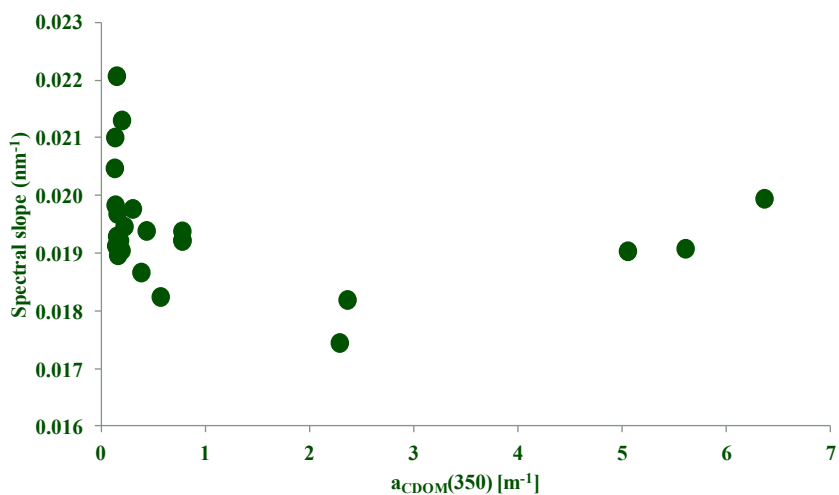

Fig. 6. Relationship between the CDOM spectral slope and $a_{\mathrm{CDOM}}(350)$ in the Beaufort Sea.

$a_{\mathrm{CDOM}} *(350)$ vs. DOC (Fig. 5) revealed a hyperbolic relationship $\left(R^{2}=0.98\right)$. This observation is in good agreement with optical theory, where absorption does not covary with increasing CDOM concentration. This may result from high riverine DOM concentrations that cause shelf shading effects that decrease CDOM light absorption efficiency, as suggested by Kowalczuk et al. (2010). Such results demonstrate the different optical properties between the eastern and western channels, and suggest that the Mackenzie River is a significant source of CDOM in the coastal area.

Our results indicated no significant difference among mean $S_{\mathrm{CDOM}}$ values between each salinity sector $\left(0.019 \pm 0.001 \mathrm{~nm}^{-1}\right.$, Fig. 6, Table 1) and a general scatter for salinity values greater than 25 (0.018 to $\left.0.023 \mathrm{~nm}^{-1}\right)$. This could be attributed to the unusually high $S_{\mathrm{CDOM}}$ values determined for the allochthonous CDOM of the Mackenzie Delta Sector that are more typical of marine $\mathrm{CDOM}$, thus preventing a clear spatial contrast in $S_{\mathrm{CDOM}}$ values throughout the system. However, high $S_{\mathrm{CDOM}}$ values for the Mackenzie Delta Sector during MALINA are similar to values previously reported for CDOM from the Mackenzie River during summer (Retamal et al., 2007; Osburn et al., 2009; Stedmon et al., 2011). Stedmon et al. (2011) and Osburn et al. (2009) suggested that such high $S_{\mathrm{CDOM}}$ values might be due to preferential adsorption by high molecular weight hydrophobic DOM components in abundant suspended sediments or to more extensive photodegradation of the high molecular weight fraction in the important Mackenzie River watershed. These results may also reflect high biological activity occurring in the numerous lakes within the Mackenzie catchment that could serve as a source of the CDOM characterized by a high CDOM spectral slope (Squires et al., 2009). We found no relationship between $a_{\mathrm{CDOM}}(350)$ and the spectral slope $S_{\mathrm{CDOM}}$ as reported by Stedmond and Markager (2001). Consequently, contributions of origin and transformations for CDOM absorption properties using $S_{\mathrm{CDOM}}$ are difficult 
Table 2. Values of diffuse attenuation coefficient of light in the UV-B (305 nm), UV-A (325, 340 and $380 \mathrm{~nm})$ and PAR spectral domains determined in surface waters of each sampling stations and among the different sectors. Environmental conditions, including solar zenith angle (SZA), wind speed, and cloud optical depth estimation are also reported, as well as the maximal depth range from which surface $K_{\mathrm{d}}(\lambda)$ values were derived.

\begin{tabular}{|c|c|c|c|c|c|c|c|c|c|}
\hline Station & $\begin{array}{r}\text { SZA } \\
\text { (deg) }\end{array}$ & $\begin{array}{r}\text { Wind } \\
\text { speed } \\
\left(\mathrm{m}^{-1}\right)\end{array}$ & $\begin{array}{r}\text { Cloud } \\
\text { optical } \\
\text { depth }\end{array}$ & $\begin{array}{r}\text { Depth } \\
\text { range } \\
(\mathrm{m})\end{array}$ & $\begin{array}{r}K_{\mathrm{d}} \\
(305 \mathrm{~nm}) \\
\left(\mathrm{m}^{-1}\right)\end{array}$ & $\begin{array}{r}K_{\mathrm{d}} \\
(325 \mathrm{~nm}) \\
\left(\mathrm{m}^{-1}\right)\end{array}$ & $\begin{array}{r}K_{\mathrm{d}} \\
(340 \mathrm{~nm}) \\
\left(\mathrm{m}^{-1}\right)\end{array}$ & $\begin{array}{r}K_{\mathrm{d}} \\
(380 \mathrm{~nm}) \\
\left(\mathrm{m}^{-1}\right)\end{array}$ & $\begin{array}{r}K_{\mathrm{d}} \\
(\mathrm{PAR}) \\
\left(\mathrm{m}^{-1}\right)\end{array}$ \\
\hline \multicolumn{10}{|c|}{ North East Sector } \\
\hline 150 & 71 & 13 & 20 & $0-10$ & - & 0.477 & 0.367 & 0.199 & 0.101 \\
\hline 170 & 56 & 5 & 20 & $0-7$ & - & 1.135 & 0.959 & 1.582 & 0.235 \\
\hline 260 & 58 & 2 & 5 & $0-30$ & 0.461 & 0.403 & 0.304 & 0.159 & 0.088 \\
\hline 110 & 56 & 13 & 15 & $0-30$ & 0.448 & 0.346 & 0.260 & 0.129 & 0.076 \\
\hline 240 & 68 & 9 & 15 & $0-30$ & - & 0.342 & 0.257 & 0.129 & 0.071 \\
\hline 135 & 59 & 9 & 10 & $0-30$ & 0.359 & 0.352 & 0.264 & 0.135 & 0.070 \\
\hline 380 & 66 & 3 & 10 & 0-6 & - & 0.635 & 0.495 & 0.241 & 0.093 \\
\hline 345 & 58 & 3 & 15 & $0-30$ & 0.366 & 0.296 & 0.224 & 0.111 & 0.072 \\
\hline 360 & 57 & 4 & 10 & $0-30$ & 0.306 & 0.283 & 0.229 & 0.117 & 0.063 \\
\hline 540 & 58 & 3 & 10 & $0-30$ & 0.361 & 0.316 & 0.241 & 0.112 & 0.064 \\
\hline 460 & 66 & 5 & 5 & $0-30$ & 0.360 & 0.337 & 0.266 & 0.127 & 0.070 \\
\hline Mean & & & & & 0.380 & 0.447 & 0.351 & 0.276 & 0.091 \\
\hline SD & & & & & 0.055 & 0.249 & 0.216 & 0.458 & 0.049 \\
\hline \multicolumn{10}{|c|}{ North West Sector } \\
\hline 760 & 62 & 2 & 10 & $0-8$ & - & 0.790 & 0.620 & 0.298 & 0.100 \\
\hline 620 & 66 & 3 & 5 & $0-5$ & - & 1.135 & 0.927 & 0.423 & 0.122 \\
\hline 660 & 79 & 4 & 5 & $0-8$ & - & - & 0.999 & 0.609 & 0.146 \\
\hline 670 & 55 & 7 & 5 & $0-5$ & - & 1.641 & 1.414 & 0.615 & 0.163 \\
\hline 780 & 80 & 2 & 10 & $0-6$ & - & 1.504 & 1.316 & 0.616 & 0.150 \\
\hline Mean & & & & & & 1.268 & 1.055 & 0.512 & 0.136 \\
\hline SD & & & & & & 0.383 & 0.318 & 0.145 & 0.025 \\
\hline
\end{tabular}

Table 3. Spectral characteristics of the three components identified by PARAFAC analysis compared to previously identified components, including Arctic and sub-Arctic studies (Stedmon et al., 2007; Walker et al., 2009; Fellman et al., 2010). Position of Ex/Em maxima of C1, $\mathrm{C} 2$ and $\mathrm{C} 3$ are deduced from their corresponding spectra reported in Fig. 8.

\begin{tabular}{|c|c|c|c|}
\hline \multirow{4}{*}{$\begin{array}{l}\text { Ex. maxima }(\mathrm{nm}) \\
\text { Em. maxima }(\mathrm{nm})\end{array}$} & \multicolumn{3}{|c|}{ Components } \\
\hline & $\mathrm{C} 1$ & $\mathrm{C} 2$ & $\mathrm{C} 3$ \\
\hline & $<240(300)$ & $<240(340)$ & $<240(275)$ \\
\hline & 404 & 472 & 314 \\
\hline Coble et al. (1998) & M & A and $\left.{ }^{(}\right)$ & $\mathrm{B}$ and $\mathrm{T}$ \\
\hline Stedmon et al. (2007) & $\mathrm{C} 3$ & $\mathrm{C} 1$ & $\mathrm{C} 4$ and $\mathrm{C} 5$ \\
\hline Walker et al. (2009) & BERC6 & BERC3 & BERC5 \\
\hline Fellman et al. (2010) & C5 & $\mathrm{CA}$ and $(\mathrm{C} 2)$ & $\mathrm{C} 8$ and $\mathrm{C} 7$ \\
\hline Source & $\begin{array}{l}\text { Marine and } \\
\text { terrestrial }\end{array}$ & $\begin{array}{l}\text { Terrestrial } \\
\text { (allochthonous) }\end{array}$ & $\begin{array}{l}\text { Amino acids } \\
\text { (autochthonous) }\end{array}$ \\
\hline
\end{tabular}

to determine, a result consistent with observations made by Matsuoka et al. (2012) for $a_{\mathrm{CDOM}}(440 \mathrm{~nm})$.

There was a linear relationship between DOC and $a_{\mathrm{CDOM}}(350)$ with salinity for the North West and Mackenzie Delta sectors (Fig. 4), whereas values remained constant for salinities $>25$ in the North East Sector. DOC or $a_{\mathrm{CDOM}}(350)$ residuals calculated as the vertical distance to the regression line represent non-conservative variations in DOC or $a_{\mathrm{CDOM}}(350)$, where positive values indicate production of DOC or CDOM and negative values degradation (Markager 

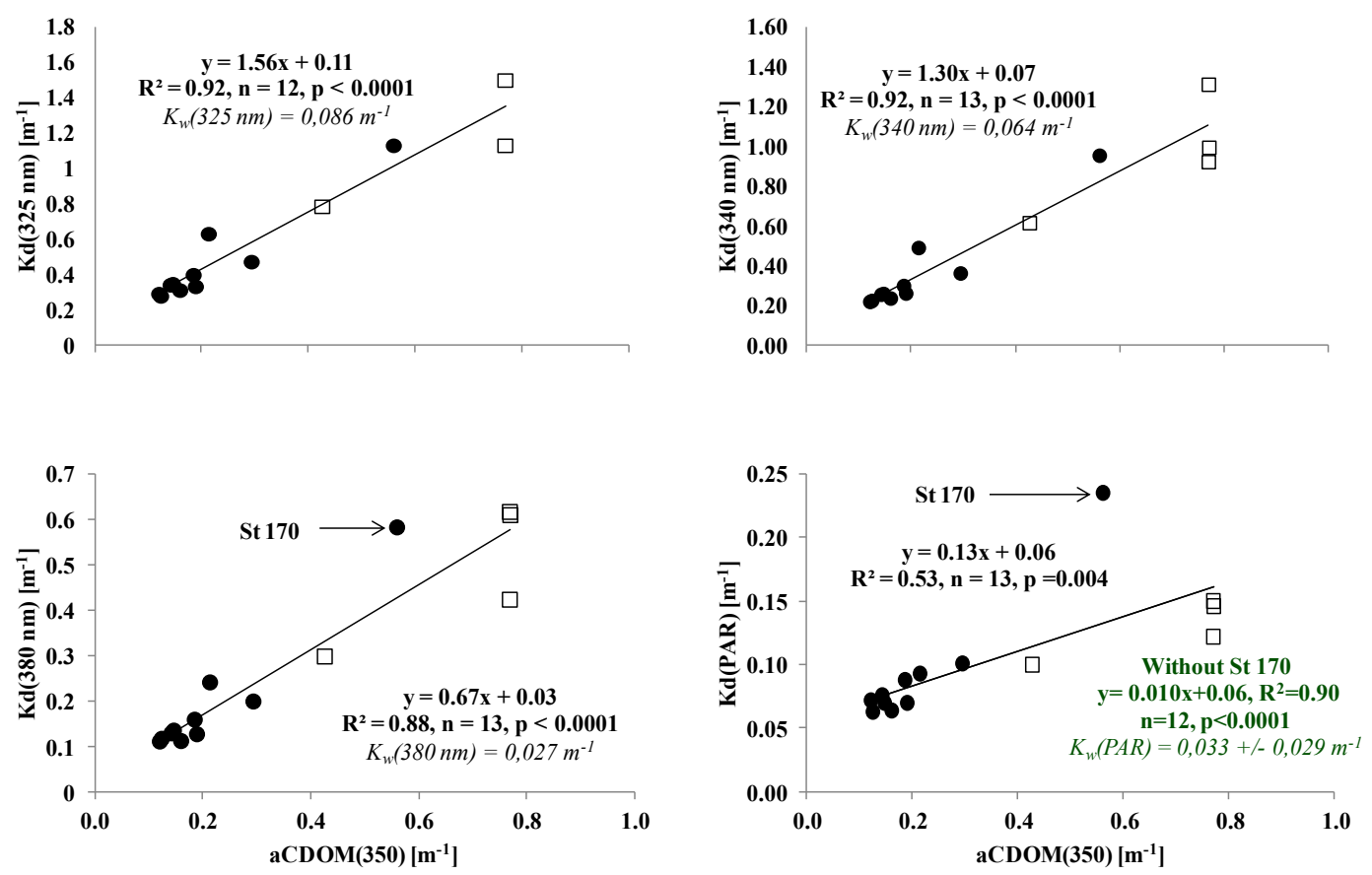

Fig. 7. Relationships between surface diffuse attenuation coefficient of light $\left(K_{\mathrm{d}}\right)$ determined in the UV-A $(325,340$ and $380 \mathrm{~nm})$ and PAR spectral domains with absorption coefficient of CDOM at $350 \mathrm{~nm}\left(a_{\mathrm{CDOM}}(350)\right)$ observed in the two saltiest surface salinity sectors (North West (squares) and North East sectors (circles)). $K_{\mathrm{W}}=$ diffuse attenuation coefficient values for pure water $\left(K_{\mathrm{W}}(\lambda)\right)$ determined by Baker and Smith (1982).

et al., 2011). The highest DOC and $a_{\mathrm{CDOM}}(350)$ residuals (+ $80 \mu \mathrm{M}$ and $+1.2 \mathrm{~m}^{-1}$, respectively) were observed at the station 394 (salinity 21.45) where the primary production was high (11.1 $\mathrm{mgC} \mathrm{m}^{-3} \mathrm{~d}^{-1}$, Patrick Raimbault, unpublished results), five-fold higher than primary production for other stations with similar salinity. Unfortunately, primary production was not available for all stations. Negative DOC and $a_{\mathrm{CDOM}}(350)$ residuals correspond, except at station 696 , to the lowest chlorophyll values (data not shown).

In order to quantify the relationship between DOC and $a_{\mathrm{CDOM}}(350)$, we plotted theses two parameters for all salinities. A significant correlation was found for the North West and Mackenzie Delta sectors $\left(r^{2}=0.99\right.$, data not shown), indicating that $99 \%$ of DOC variability is explained by that in the colored fraction of DOM. Matsuoka et al. (2012), during the same cruise, observed a similar relationship between DOC content and $a_{\mathrm{CDOM}}$ (440). The correlation was lower $\left(R^{2}=0.86\right)$ in the North East Sector. The solar radiation reaching the sea surface was, due to the presence of persistent clouds, low during summer 2009 (see Sect. 3.1). This low light availability probably prevented CDOM from photobleaching processes, and thus preserved the $a_{\mathrm{CDOM}}(350) / \mathrm{DOC}$ relationship.

Based on the $a_{\mathrm{CDOM}}(350)$ and DOC distributions alone, it appears that the origin of DOM in each region is shifted throughout the shelf system. In the Mackenzie Delta and North West sectors (salinity $<25$ ), the concentrations re- flect the mixing process of the Mackenzie's terrestrial input, except locally (station 394) where primary production enhanced both DOC and $a_{\mathrm{CDOM}}(350)$, while in the saltiest surface waters (North East Sector), autochthonous DOM appears to dominate. Sea ice formation/brine rejection and upwelling processes are common physical features in this salty area and have the capacity to both deliver new DOM and enhance surface in situ production of DOM (Carmack and Macdonald, 2002; Barber and Hanesiak, 2004; Guéguen et al., 2007; Walker et al., 2009; Mucci et al, 2010). Additional CDOM could be produced by zooplankton and bacterioplankton communities (Nelson et al., 2004). DOM introduced by either process could have the capacity to create the attenuation patterns for both UV-A and PAR seen in Fig. 3. An upwelling event close to the Cape Bathurst area (Fig. 1) was clearly identified during our sampling period and has been previously observed by Mucci et al. (2010). It enhanced primary production $\left(37.9 \mathrm{mgC} \mathrm{m}^{-3} \mathrm{~d}^{-1}\right.$, P. Raimbault, unpublished results) in the surface waters surrounding Cape Bathurst, manifested as the second highest surface chlorophyll $a$ concentrations $\left(\sim 1.72 \mu \mathrm{g} \mathrm{L}^{-1}\right)$ observed at station 170 (Josephine Ras, LOV, personal communication). Subsequent organic by-products from this productive area could explain the high values for DOC, $a_{\mathrm{CDOM}}(350)$ and $K_{\mathrm{d}}$ (UVA and PAR) observed at this station (Tables 1 and 2).

In general, these results highlighted both allochthonous and autochthonous origins for DOM in the surface waters 

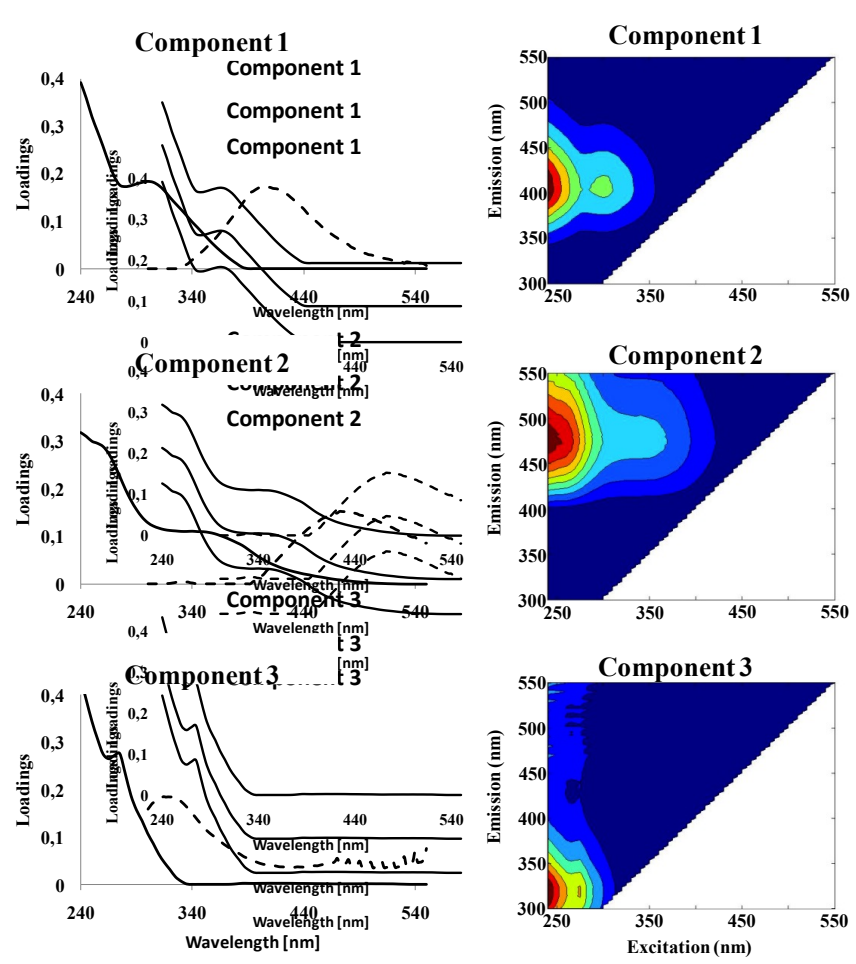

Fig. 8. Emission (dashed line) and excitation (solid line) spectra (left panels) and contour plots (right panels) of the three main fluorescent components identified in the data set $(n=54)$. Ex/Em component 1: 240 (300)/404; Ex/Em component 2: 240 (340)/472 and Ex/Em component 3: $240(275) / 314$.

of the Canadian shelf. An additional feature of the source material can be seen in the estimation of the optically inactive fraction of the DOC pool in the study area. Using the y-intercept of the DOC vs. $a_{\mathrm{CDOM}}(350)$ relationship (i.e. $a_{\mathrm{CDOM}}(350)=0 \mathrm{~m}^{-1}$ ), we estimate that about $64 \mu \mathrm{M}$ of the DOC do not absorb radiation at $350 \mathrm{~nm}$ in the Mackenzie River. Such results indicated that, on average, $\sim 16 \%$ of the DOC is optically inactive at $350 \mathrm{~nm}$ in the Mackenzie River, with a result similar for $a_{\mathrm{CDOM}}(440)$ from Matsuoka et al. (2012). Based on a carbon content of $\sim 400 \mu \mathrm{M} \mathrm{C}$ in the river mouth (Table 1), the DOC discharged by the Mackenzie River can be estimated during the MALINA cruise (30 July27 August) to be approximately $0.22 \mathrm{TgC}$ (i.e. 10 to $20 \%$ of annual DOC fluxes and 6 to $10 \%$ of annual total organic carbon fluxes; Raymond et al., 2007; MacDonald et al;, 1998). Considering that $\sim 64 \mu \mathrm{M} \mathrm{C}$ does not absorb radiation in the $\mathrm{UV}$, we can estimate that about $0.18 \mathrm{TgC}$ of the DOC discharge can be categorized as CDOM.

$K_{\mathrm{d}}(\mathrm{UV}-\mathrm{A})$ and $K_{\mathrm{d}}(\mathrm{PAR})$ in the North West and North East sectors (i.e. at salinity $>20$; where radiometric measurements were performed) were significantly correlated to $a_{\mathrm{CDOM}}(350)$ values (Fig. 7), except for the single $K_{\mathrm{d}}$ (PAR) value observed at station 170 where the second highest chlorophyll $a$ content and highest primary production oc- curred $\left(1.72 \mu \mathrm{g} \mathrm{L}^{-1}\right.$ and $37.9 \mathrm{mgC} \mathrm{m}^{-3} \mathrm{~d}^{-1}$, respectively, data not shown), and $a_{\mathrm{CDOM}}(350)=0.56 \mathrm{~m}^{-1}$. Interestingly, the y-intercept values of these relationships (Fig. 7) were in the range of attenuation coefficient values found for pure water, $K_{\mathrm{w}}(\lambda)$, determined by Baker and Smith (1982). Therefore, it can be argued that CDOM is the dominant attenuator for not only UV-A radiation, but also for PAR. This is in good agreement with Retamal et al. (2008) and their report of control of PAR-light absorbance by CDOM in the Beaufort Sea.

\subsubsection{Fluorescent DOM}

Three fluorescent components (Fig. 8, Table 3) were identified with PARAFAC analysis using a total of 54 EEM spectra collected from surface waters and the deep chlorophyll maximum (DCM) for the stations investigated during the MALINA cruise. The low number of fluorescent compounds identified is probably due to the degradation processes of labile material during storage. Thus, $\mathrm{C} 3$ component data should be taken with caution due to possible degradation processes during storage. In the Mackenzie Delta Sector (salinity $<15$ ), the relative contribution of the aquatic DOM component $\mathrm{C} 1(52 \pm 2 \%)$ and terrestrial component $\mathrm{C} 2(36 \pm 6 \%)$ reached their highest contribution, while $\mathrm{C} 3$ $(12 \pm 7 \%)$ was around 5 times lower than the same component determined for the saltiest surface waters. In the North East Sector (salinity $>25$ ), the relative contribution of fluorescent components was clearly dominated by the proteinlike C3 $(57 \pm 7 \%)$, followed by the ubiquitous humic-like $\mathrm{C} 1(30 \pm 4 \%)$ and the terrestrial $\mathrm{C} 2(13 \pm 4 \%)$. In surface waters of the North West Sector $(15<$ salinity $<25)$, we observed a co-dominance of both $\mathrm{C} 1(40 \pm 8 \%)$ and $\mathrm{C} 3$ $(36 \pm 13 \%)$ while the relative contribution of the terrestrial component $\mathrm{C} 2$ was around two times lower $(23 \pm 6 \%)$.

These three components have been previously identified in various natural waters. Indeed, component $\mathrm{C} 1$ has been reported as a ubiquitous FDOM component derived from the microbial degradation of phytoplankton by-products (Nagata, 2000; Stedmon and Markager, 2005; Zhang et al., 2009), as well as originating from specific Arctic terrestrial sources at low salinity (Walker et al., 2009) and various coastal and estuarine environments reported in Japan (Yamashita et al., 2008), the southeastern USA coast (Kowalczuk et al., 2009), in Liverpool Bay (Yamashita et al., 2011), and in Hudson Bay (Guéguen et al., 2011). Component 2 (C2) has been previously associated with high molecular weight and aromatic terrestrial organic matter (Stedmon et al., 2003; Walker et al. (2009). The low Ex/Em maxima of component 3 (C3) is comparable with protein-like components previously observed in surface waters for both fresh and marine systems (Coble, 1996; Yamashita and Tanoue, 2003; Para et al., 2010). There were significant linear relationships between $\mathrm{C} 1$ and $\mathrm{C} 2$ fluorescence and salinity (negative linear correlation, Fig. 9), indicating that $\mathrm{C} 1$ and $\mathrm{C} 2$ are certainly controlled by mixing processes even if local 

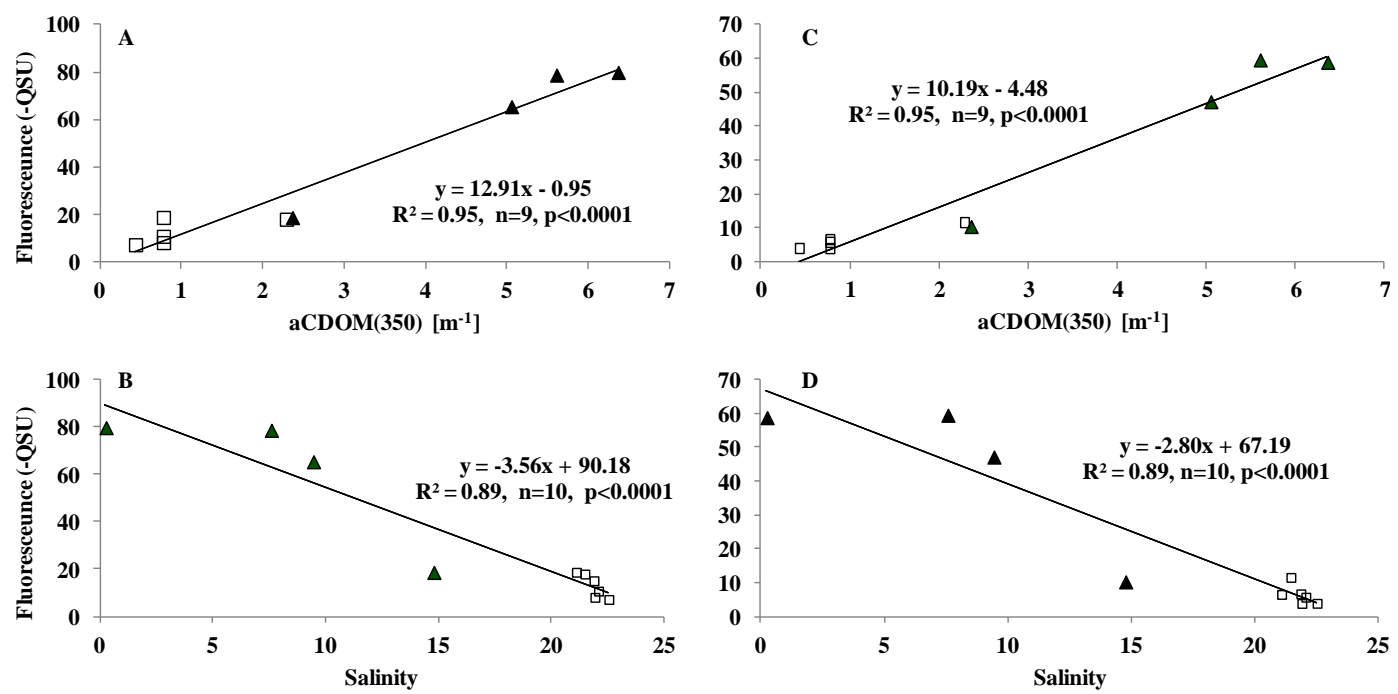

Fig. 9. Relationships observed between $\mathrm{C} 1$ (A), (B) and C2 (C), (D) components with absorption coefficient of CDOM at $350 \mathrm{~nm}$ $\left(a_{\mathrm{CDOM}}(350)\right)$ and salinity determined in the Mackenzie Delta (triangles) and North West sectors (squares).

primary production impact can not be precluded. The fluorescence intensity of $\mathrm{C} 1$ and $\mathrm{C} 2$ components are strongly correlated $\left(R^{2}=0.89\right)$ within the Mackenzie Delta and North West sectors, but this correlation decreased with increasing salinity in the North West Sector $\left(R^{2}=0.77\right.$ and 0.33 , respectively). This decoupling reinforces the hypothesis that there is a common (terrestrial) origin for both the $\mathrm{C} 1$ and C2 components in the Mackenzie Delta Sector, whereas the $\mathrm{C} 1$ component is probably contributed by in situ marine production with increasing salinity $(>15)$. The positive linear relations between both $\mathrm{C} 1$ and $\mathrm{C} 2$ and $a_{\mathrm{CDOM}}(350)$ in the Mackenzie Delta and North West sectors $\left(R^{2}=0.95\right.$, Fig. 9) suggest that fluorescence may be used as a proxy for the absorption coefficient. The fluorescence/salinity residuals for $\mathrm{C} 1$ and $\mathrm{C} 2$ did not match chlorophyll $a$ content or primary production.

Therefore, during our study period, the FDOM content in surface waters of the Canadian shelf was strongly influenced by allochthonous DOM that originated from the Mackenzie River, except in the saltiest waters where autochthonous in situ biological FDOM prevailed. Surprisingly, the allochthonous fluorescent DOM carried by the Mackenzie into the Beaufort Sea presents both a terrestrial humic and an aquatic DOM signature. Indeed, the fluorescence intensity of the aquatic DOM component $\mathrm{C} 1$ co-dominated with the terrestrial humic-like component $\mathrm{C} 2$ in controlling the overall allochthonous fluorescent DOM pool of the Mackenzie Delta Sector. Interestingly, the overall distribution of the terrestrial component $\mathrm{C} 2$ appeared restricted to the Mackenzie Delta Sector and correlated well with the strongly absorbing allochthonous DOM observed, while the surface distribution of the aquatic DOM component $\mathrm{C} 1$ appeared more widespread in the whole system.
The Mackenzie Delta is composed of numerous ( $\sim 45000)$ shallow (1.6 $\mathrm{m}$ depth on average) macrophyterich lakes (Emmerton et al., 2007; Squires et al., 2009) that significantly influence the Mackenzie DOM content prior to its marine discharge in summer (Emmerton et al., 2008; Gareis et al., 2010). In addition, macrophyte and phytoplankton degradation/exudation processes in fresh shallow (Zhang et al., 2009) and marine systems can lead to the production of a marine humic-like fluorescent component (M peak; Coble, 1996) comparable to our $\mathrm{C} 1$. Therefore, the strong aquatic fluorescent DOM fraction observed in the Mackenzie Delta Sector during this study may partly originate from high biological activity (Squires et al., 2009) occurring in these catchments. This finding complements previous work and provides valuable evidence concerning the Mackenzie organic matter quality, which is depleted in humic material as reported previously during summer time; this depletion is attributed to (i) a long freshwater residence time in Mackenzie catchments (Retamal et al., 2007), (ii) a preferential sorption of the high molecular weight hydrophobic DOM components to abundant suspended sediments (Stedmon et al., 2011) and (iii) a more extensive photodegradation of the high molecular weight fraction occurring in the Mackenzie watershed during summer (Osburn et al., 2009).

\section{Summary}

In the present study we reported radiometric and biogeochemical data in the Beaufort Sea during summer 2009. This period was, due to cloud coverage, characterized by low atmospheric solar radiation that very likely limited DOM photodegradation processes in surface waters. In the water column, light behaviour was mainly controlled by 
CDOM content both for UV-A and PAR radiation. Along the Mackenzie Delta and North West sectors of the Beaufort Sea, the DOC and CDOM dynamic is controlled by mixing processes, although, locally, primary productivity can contribute to the CDOM signal. In this study $a_{\mathrm{CDOM}}(350)$ can be used as a DOC proxy over the studied area. During the summer period $16 \%$ of the DOC did not absorb light at $350 \mathrm{~nm}$. Fluorescent DOM in the Mackenzie Delta Sector exhibited both a terrestrial "humic-like" signature (component $\mathrm{C} 2$ ) and an in situ aquatic signature (component $\mathrm{C} 1$ ). Fluorescent $\mathrm{C} 1$ and $\mathrm{C} 2$ components can be used as $a_{\mathrm{CDOM}}(350)$ proxy in the Mackenzie Delta and North West sectors.

Acknowledgements. This study was conducted as part of the Malina Scientific Program funded by ANR (Agence Nationale de la Recherche), INSU-CNRS (Institut National des Sciences de l'Université - Centre National de la Recherche Scientifique), CNES (Centre National d'Etudes Spatiales) and ESA (European Space Agency). We are grateful to M. Babin PI of the Malina Project as well as the captain and crews of the Canadian Icebreaker CCGS Amundsen. We also thank S. Belanger, A. Mucci, B. Lansard and C. Stedmon for SIM/Chl $a$ data and PARAFAC analysis. Special thanks are due to C. Marec and Y. Graton for water sampling. We are grateful to M. Tedetti and M. Goutx for their help with the fluorescence analysis, and to J. Ras and P. Raimbault for unpublished chlorophyll $a$ and primary production data. R. Sempéré acknowledges equipment funding from the French Provence Alpes Côte d'Azur region. PhD scholarship to J. Para was provided by the Region of Provence Alpes Côte d'Azur and AIRPACA. The authors acknowledge anonymous reviewers, G. Herndl for handling the manuscript as an editor, and P. K. Kowalczuk for constructive comments on the manuscript.

Edited by: G. Herndl

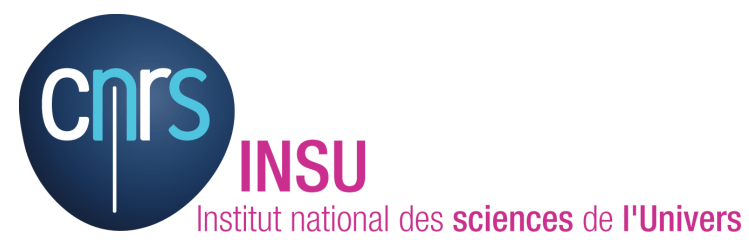

The publication of this article is financed by CNRS-INSU.

\section{References}

Babin, M., Stramski, D., Ferrari, G. M., Claustre, H., Bricaud, A., Obolensky, G., and Hoepffner, N.: Variations in the light absorption coefficients of phytoplankton, nonalgal particles, and dissolved organic matter in coastal waters around Europe, J. Geophys. Res., 108, 3211, doi:10.1029/2001JC000882, 2003.

Baker, K. S. and Smith, R. C.: Bio-optical classification and model of natural waters, Limnol. Oceanogr., 27, 500-509, 1982.

Barber, D. G. and Hanesiak, J.: Meteorological forcing of sea ice concentrations in the Southern Beaufort Sea over the period 1978 to 2001, J. Geophys. Res., 109, C06014, doi:10.1029/2003JC002027, 2004

Belzile, C., Roesler, C. S., Christensen, J. P., Shakhova, N., and Semiletov, I.: Fluorescence measured using the WETStar DOM fluorometer as a proxy for dissolved matter absorption, Estuar. Coast. Shelf Sci., 67, 441-449, 2006.

Carmack, E. C. and Macdonald, R. W.: Oceanography of the Canadian shelf of the Beaufort Sea: a setting for marine life, Arctic, 55, 29-45, 2002.

Coble, P. G.: Characterization of marine and terrestrial DOM in seawater using excitation emission matrix spectroscopy, Mar. Chem., 51, 325-346, 1996.

Coble, P. G., Schultz, C. A., and Mopper, K.: Fluorescence contouring analysis of DOC intercalibration experiments samples: a comparison of techniques, Mar. Chem., 41, 173-178, 1993.

Coble, P. G., Del Castillo, C. E., and Avril, B.: Distribution and optical properties of CDOM in the Arabian Sea during the 1995 southwest monsoon, Deep-Sea Res. Pt. II, 45, 2195-2223, 1998.

Del Vecchio, R. and Blough, N. V. : Spatial and seasonal distribution of chromophoric dissolved organic matter and dissolved organic carbon in the Middle Atlantic Bight, Mar. Chem. 89, 169-187, 2004.

Dittmar, T. and Kattner, G.: The biogeochemistry of the river and shelf ecosystem of the Arctic Ocean: a review, Mar. Chem., 83, 103-120, 2003

Emmerton, C. A., Lesack, L. F. W., and Marsh, P.: Lake abundance, potential water storage, and habitat distribution in the Mackenzie River Delta, western Canadian Arctic, Water Resour. Res., 43, W05419, doi:10.1029/2006WR005139, 2007.

Emmerton, C. A., Lesack, L. F. W., and Vincent, W. F.: Mackenzie River nutrient delivery to the Arctic Ocean and effects of the Mackenzie Delta during open water conditions, Glob. Biogeochem. Cy., 22, GB1024, doi:10.1029/2006GB002856, 2008.

Fellman, J. B., Spencer, R. G. M., Hernes, P. J., Edwards, R. T., D'Amore, D. V., and Hood, E.: The impacts of glacier runoff on the biodegradability and biochemical composition of terrigenous dissolved organic matter in near-shore marine ecosystems, Mar. Chem., 121, 112-122, 2010.

Foley, J. A.: Tipping points in the tundra, Science, 310, 627-628, 2005.

Gareis, J. A. L., Lesack, L. F. W., and Bothwell, M. L.: Attenuation of in situ UV radiation in Mackenzie Delta lakes with varying dissolved organic matter compositions, Water Resour. Res., 46, W09516, doi:10.1029/2009WR008747, 2010.

Gordeev, V. V.: Fluvial sediment flux to the Arctic Ocean, Geomorphology, 80, 94-104, doi:10.1016/j.geomorph.2005.09.008, 2006.

Guéguen, C., Guo, L., Yamamoto-Kawai, M., and Tanaka, N.: Colored dissolved organic matter dynamics across the shelf-basin interface in the western Arctic Ocean, J. Geophys. Res. 112, C05038, doi:10.1029/2006JC003584, 2007.

Guéguen, C., Granskog, M. A., McCullough G., and Barber D. G.: Characterisation of colored dissolved organic matter in Hudson Bay and Hudson Strait using parallel factor analysis, J. Mar. Syst., 88, 423-433, 2011.

Guo, L., Ping, C. L., and Macdonald, R. W.: Mobilization pathways of organic carbon from permafrost to arctic rivers in a changing climate, Geophys. Res. Lett., 34, L13603, doi:10.1029/2007GL030689, 2007. 
IPCC: Climate Change: The Physical Science Basis, Contribution of Working Group I to the Fourth Assessment Report of the IPCC (Cambridge University Press, Cambridge), chap. 7, 514515, 2007.

Jin, Z., Charlock, T., Smith Jr., W., and Rutledge, K.: A parameterization of ocean surface albedo, Geophys. Res. Let., 31, L22301, doi:10.1029/2004GL021180, 2004.

Johannessen, S. C. and Miller, W. L.: Quantum yield for the photochemical production of dissolved inorganic carbon in seawater, Mar. Chem., 76, 271-283, 2001.

Kowalczuk, P., Cooper, W. J., Durako, M.J., Young, H., and Kahn, A. E.: Characterization of dissolved organic matter fluorescence in the South Atlantic Bight with use of PARAFAC model: interannual variability, Mar. Chem., 113, 182-196, 2009.

Kowalczuk, P., Cooper, W. J., Durako, M. J., Kahn, A. E., Gonsior, M., and Young, H.: Characterization of dissolved organic matter fluorescence in the South Atlantic Bight with use of PARAFAC model: Relationships between fluorescence and its components, absorption coefficients and organic carbon concentrations, Mar. Chem., 118, 22-36, 2010

Lawrence, D. M. and Slater, A. G.: A projection of severe nearsurface permafrost degradation during the 21st century, Geophys. Res. Lett., 32, L24401, doi:10.1029/2005GL025080, 2005.

Macdonald, R. W., Solomon, S. M., Cranston, R. E., Welch, H. E., Yunker, M. B., and Gobeil, C.:. A sediment and organic carbon budget for the Canadian Beaufort Sea, Mar. Geol., 144, 255-273, 1998.

Markager, S., Stedmon, C. A., and Søndergaard, M.,: Seasonal dynamics and conservative mixing of dissolved organic matter (DOM) in the temperate eutrophic estuary Horsens Fjord, Estuar. Coast. Shelf Sci., 92, 376-388, 2001.

Matsuoka, A., Hill, V., Huot, Y., Bricaud, A., and Babin, M.: Seasonal variability in the light absorption properties of western Arctic waters: parameterization of the individual components of absorption for ocean color applications, J. Geophys. Res., 116, C02007, doi:10.1029/2009JC005594, 2011.

Matsuoka, A., Bricaud, A., Benner, R., Para, J., Sempéré, R., Prieur, L., Bélanger, S., and Babin, M.: Tracing the transport of colored dissolved organic matter in water masses of the Southern Beaufort Sea: relationship with hydrographic characteristics, Biogeosciences, 9, 925-940, doi:10.5194/bg-9-925-2012, 2012.

Mucci, A., Lansard, B., Miller, L. A., and Papakyriakou, T. N.: $\mathrm{CO}_{2}$ fluxes across the air-sea interface in the southeastern Beaufort Sea: Ice-free period, J. Geophys. Res., 115, C04003, doi:10.1029/2009JC005330, 2010.

Nagata, T.: Production mechanisms of Dissolved Organic Matter, in Microbial Ecology of the Oceans, edited by: Kirchman, D. L., 121-152, 2000.

Nelson, N. B, Carlson, C. A., and Steinberg, D. K.: Production of chromophoric dissolved organic matter by Sargasso Sea microbes, Mar. Chem., 89, 273-287, 2004.

O'Brien, M. C., Macdonald, R. W., Melling, H., and Iseki, K.: Particle fluxes and geochemistry on the Canadian Beaufort Shelf: implications for sediment transport and deposition, Cont. Shelf Res., 26, 41-81, 2006.

Opsahl, S., Benner, R., and Amon, R.: Major flux of terrigenous dissolved organic matter through the Arctic Ocean, Limnol. Oceanogr., 44, 2017-2023, 1999.
Osburn, C. L., O'Sullivan, D. W., and Boyd, T. J.: Increases in the longwave photobleaching of chromophoric dissolved organic matter in coastal waters, Limnol. Oceanogr., 54, 145-159, 2009.

Para, J., Coble, P. G., Charrière, B., Tedetti, M., Fontana, C., and Sempéré, R.: Fluorescence and absorption properties of chromophoric dissolved organic matter (CDOM) in coastal surface waters of the northwestern Mediterranean Sea, influence of the Rhône River, Biogeosciences, 7, 4083-4103, doi:10.5194/bg-74083-2010, 2010.

Raymond, P. A., McClelland, J. W., Holmes, R. M., and Zhulidov, A. V.: Flux and age of dissolved organic carbon exported to the Arctic Ocean: A carbon isotopic study of the five largest Arctic rivers, Global Biogeochem. Cy., 21, GB4011, doi:10.1029/2007GB002934, 2007.

Retamal, L., Vincent, W. F., Martineau, C., and Osburn, C. L.: Comparison of the optical properties of dissolved organic matter in two river in?uenced coastal regions of the Canadian Arctic, Estuar. Coast. Shelf Sci., 72, 261-272, 2007.

Retamal, L., Bonilla, S., and Vincent, W. F.: Optical gradients and phytoplankton production in the Mackenzie River and the coastal Beaufort Sea, Polar Biol., 31, 363-379, 2008.

Sempéré, R., Tedetti, M., Panagiotopoulos, C., Charrière, B., and Van Wambeke, F.: Distribution and bacterial availability of dissolved neutral sugars in the South East Pacific, Biogeosciences, 5, 1165-1173, doi:10.5194/bg-5-1165-2008, 2008.

Smith, R. C. and Baker, K. S.: The analysis of ocean optical data. Proceedings of The Society of Photo-Optical Instrumentation Engineers, Ocean Optics VII, 489, 119-126, 1984.

Sohrin, R. and Sempéré, R.: Seasonal variation in total organic carbon in the Northeast Atlantic in 2000-2001, J. Geophys. Res., 110, C10S90, doi:10.1029/2004JC002731, 2005.

Squires, M. M., Lesack, L. F. W., Hecky, R. E., Guildford, S. J., Ramlal, P., and Higgins, S. N.: Primary Production and Carbon Dioxide Metabolic Balance of a Lake-Rich Arctic River Floodplain: Partitioning of Phytoplankton, Epipelon, Macrophyte, and Epiphyton Production Among Lakes of the Mackenzie Delta, Ecosystems, 12, 853-872, doi:10.1007/s10021-0099263-3, 2009.

Stedmon, C. A. and Bro, R.: Characterizing dissolved organic matter fluorescence with parallel factor analysis: A tutorial, Limnol. Oceanogr. Methods, 6, 572-579, 2008.

Stedmon, C. A. and Markager, S.: The optics of chromophoric dissolved organic matter (CDOM) in the Greenland Sea: An algorithm for differentiation between marine and terrestrially derived organic matter, Limnol. Oceanogr., 46, 2087-2093, 2001.

Stedmon, C. A. and Markager, S.: Tracing the production and degradation of autochthonous fractions of dissolved organic matter using fluorescence analysis, Limnol. Oceanogr., 50, 1415-1426, 2005.

Stedmon, C. A., Markager, S., and Kaas, H.: Optical properties and signatures of chromophoric dissolved organic matter (CDOM) in Danish coastal waters, Estuar. Coast. Shelf Sci., 51, 267-278, 2000.

Stedmon, C. A., Markager, S., and Bro, R.: Tracing dissolved organic matter in aquatic environments using a new approach to fluorescence spectroscopy, Mar. Chem., 82, 239-254, doi:10.1016/S0304-4203(03)00072-0, 2003.

Stedmon, C. A., Thomas, D. N., Granskog, M., Kaartokallio, H., Papadimitriou, S., and Kuosa, H.: Characteristics of dissolved 
organic matter in Baltic coastal sea ice: allochthonous or autochthonous origins?, Environ. Sci. Technol., 41, 7273-7279, 2007.

Stedmon, C. A., Amon, R. M. W., Rinehart, A. J., and Walker, S. A.: The supply and characteristics of colored dissolved organic matter (CDOM) in the Arctic Ocean: Pan Arctic trends and differences, Mar. Chem., 124, 108-118, 2011.

Tarnocai, C., Canadell, J. G., Schuur, E. A. G., Kuhry, P., Mazhitova, G., and Zimov, S.: Soil organic carbon pools in the northern circumpolar permafrost region, Glob. Biogeochem. Cy., 23, GB2023, doi:10.1029/2008GB003327, 2009.

Tedetti, M., Sempéré, R., Vasilkov, A., Charrière, B., Nérini, D., Miller, W. L., Kawamura, K., and Raimbault, P.: High penetration of ultraviolet radiation in the south east Pacific waters, Geophys. Res. Lett., 34, L12610, doi:10.1029/2007GL029823, 2007.

Tedetti, M., Guigue, C., and Goutx, M.: Utilization of a submersible UV fluorometer for monitoring anthropogenic inputs in the Mediterranean coastal waters, Mar. Pollut. Bull., 60, 350362, 2010.

Walker, S. A., Amon, R. M. W., Stedmon, C., Duan, S., and Louchouarn, P.: The use of PARAFAC modeling to trace terrestrial dissolved organic matter and fingerprint water masses in coastal Canadian Arctic surface waters, J. Geophys. Res., 114, G00F06, doi:10.1029/2009JG000990, 2009.
Walvoord, M. A. and Striegl, R. G.: Increased groundwater to stream discharge from permafrost thawing in the Yukon River basin: potential impacts on lateral export of carbon and nitrogen, Geophys. Res. Lett., 34, L12402, doi:10.1029/2007GL030216, 2007.

Yamashita, Y. and Tanoue, E.: Chemical characterization of proteinlike fluorophores in DOM in relation to aromatic amino acids, Mar. Chem., 82, 255-271, 2003.

Yamashita, Y., Jaffé, R., Maie, N., and Tanoue, E.:Assessing the dynamics of dissolved organic matter (DOM) in coastal environments by excitation and emission matrix fluorescence and parallel factor analysis (EEM-PARAFAC), Limnol. Oceanogr., 53, 1900-1908, 2008.

Yamashita, Y., Cory R. M., Nishioka J., Kuma K., Tanoue, E., and Jaffé, R.: Fluorescence characteristics of dissolved organic matter in the deep waters of the Okhotsk Sea and the northwestern North Pacific Ocean, Deep-Sea Res. Pt. II, 57, 1478-1485, 2010.

Yamashita, Y., Panton, A., Mahaffey, C., and Jaffé, R.: Assessing the spatial and temporal variability of dissolved organic matter in Liverpool Bay using excitation-emission matrix fluorescence and parallel factor analysis, Ocean Dyn., 61, 5, doi:10.1007/s10236-010-0365-4, 2011

Zhang, Y., van Dijk, M. A., Liu, M., Zhu, G., and Qin, B.: The contribution of phytoplankton degradation to chromophoric dissolved organic matter (CDOM) in eutrophic shallow lakes: field and experimental evidence, Water. Res., 43, 4685-4697, 2009. 